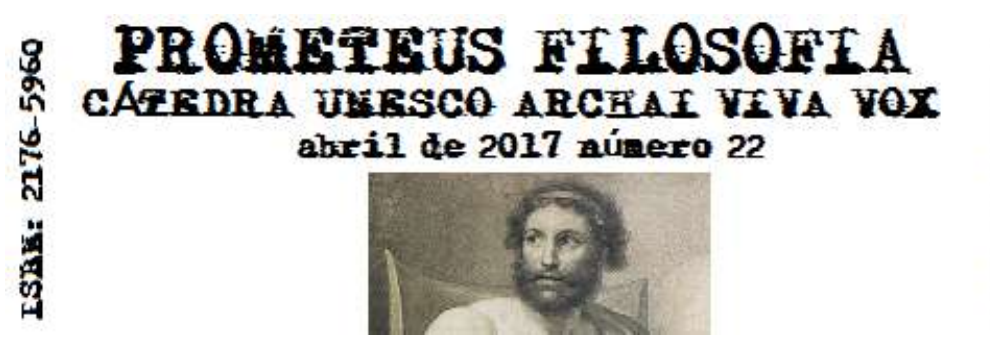

\title{
RESENHA
}

\section{DINUCCI, A. L.; DUARTE, V. Introdução à lógica proposicional estoica. São Cristóvão: Editora UFS, 2016.}

\section{Lauro Iane de Morais Graduando em Filosofia - bolsista PIBIC - UFS}

Lançado em 2016 pela Editora UFS e escrito por Aldo Dinucci, professor adjunto do departamento de Filosofia, principal comentador e tradutor de Epicteto em português, e Valter Duarte, doutorando em Filosofia pela UERJ (2016) e mestre em Filosofia pela UFS (2016), que recentemente defendeu sua dissertação intitulada Notas sobre a Lógica Estoica ${ }^{1}$, que versa sobre o tema do presente livro a ser resenhado. Ademais, contam como coautores Luís Márcio Fontes et al.

A Introdução à lógica proposicional estoica divide-se em Prefácio, Introdução, Taxonomia dos Asseríveis da Lógica Proposicional Estoica, Teoria Estoica dos Argumentos e Solução de Silogismos Estoicos. Além de Referências Bibliográficas, há nele sete apêndices para ajudar o leitor a se familiarizar com os termos, conceitos e nomes dos filósofos estoicos.

$\mathrm{Na}$ Introdução, encontramos um breve apanhado histórico sobre o desenvolvimento da lógica estoica. Segundo Duarte e Dinucci, apesar dessa ter sido primeiro formulada por Crisipo, a lógica estoica traça suas raízes à Escola Megárica, pois esta, além de ter criado certos paradoxos lógicos, examinou questões de modalidade lógica e iniciou o debate acerca das condicionais, temas que permearam desenvolvimentos posteriores estoicos. Todavia, como notam Kneale e Kneale (1962, p.139), podemos datar a divisão tripartite da filosofia estoica - i.e., lógica, física e ética

\footnotetext{
${ }^{1}$ Duarte, V. Notas sobre a Lógica Estoica. Dissertação não publicada. São Cristóvão: 2016.
} 
- já a partir de sua fundação, com Zenão de Cítio; este, por sua vez, foi aluno dos megáricos Estilpo e, possivelmente, Diodoro. Sabemos que esses últimos já estudavam dialética, disciplina que envolvia questões de modalidade- que já vinha sendo pesquisada por Aristóteles e outros peripatéticos ${ }^{2}-$, paradoxos e sentenças (por conta da escassez de fontes, não podemos saber em qual sentido os megáricos teriam utilizado esse último termo) $)^{3}$. Todavia, isso é suficiente para termos pistas do que provavelmente Zenão estaria pesquisando, já que ele acreditara que o estudo da dialética permitiria aos alunos resolverem paradoxos. ${ }^{4}$ Em vista disso, talvez seja melhor compreendermos a lógica estoica como uma criação de Zenão que foi posteriormente aperfeiçoada por Crisipo, quem teria criado os fundamentos básicos que são analisados através do livro ao qual esta resenha se dedica. Ademais, apesar de não termos evidência textual de que Crisipo tenha sido aluno dos megáricos, podemos seguramente dizer que ele sofreu forte influência do pensamento megárico, escrevendo obras contra eles 5 .

Quanto às fontes para o estudo da lógica estoica, poucas nos restaram. Entre as principais, temos Sexto Empírico, que escreve contra os estoicos, e Diógenes Laércio, que escreve doxografias. Ademais, os autores utilizam o Stoicorum Veterum Fragmenta e outras obras de autores como Galeno, AuloGélio et al. para auxiliá-los. Segundo Dinucci (2016, p.16), comentadores importantes, tais como Prantl e Zeller, teriam emitido juízos desfavoráveis a lógica estoica devido ao caráter esparso das fontes e a má compreensão das mesmas. Peirce teria sido o primeiro a perceber que o debate acerca das condicionais na Antiguidade era correlato ao debate que ocorria em seu tempo, mas foi Łukasiewicz que abriu precedentes para que estudos posteriores, tais como os de Kneale e Kneale, Benson Mates et al, pudessem ocorrer, pois ele foi o primeiro a perceber que a lógica estoica tratava-se de uma lógica proposicional.

Ademais, na Taxonomia dos Asseríveis da Lógica Proposicional Estoica, encontramos a divisão da lógica estoica, a qual, somando-se às divisões preliminares da Introdução, pode ser brevemente esquematizada: a lógica (1) divide-se em dialética (1.1) e retórica (1.2). Por sua vez, (1.1) divide-se no tópico das vozes (1.1.1) e no tópico dos significados (1.1.2); (1.1.2) divide-se no tópico das representações (1.1.2.1) e

\footnotetext{
${ }^{2}$ Cf. Kneale e Kneale, 1962, p.81.

${ }^{3}$ Cf. Kneale e Kneale, 1962, p.118.

${ }^{4}$ Plutarco apud Kneale e Kneale, 1962, p. 115.

${ }^{5}$ DIÓGENES LAÉRCIO, VII, 191 e 194.
} 
dizíveis (1.1.2.2) ${ }^{6}$; (1.1.2.2) divide-se em incompletos (1.1.2.2.1) e completos (1.1.2.2.2). Para facilitarmos a leitura, estabeleçamos que (1.1.2.2.2) = a. Portanto, no tópico dos asseríveis completos (a) encontramos as questões (a.1), ordens (a.2), súplicas (a.3), asseríveis (a.4) et al. ${ }^{7}$ Já, os asseríveis completos (a.4), que são os portadores primários de valor verdade ou falsidade ${ }^{8}$, distinguem-se em simples (a.4.1) e nãosimples (a.4.2); (a.4.1) subdividem-se em afirmativos (a.4.1.1) e negativos (a.4.1.2). Os asseríveis simples afirmativos (a.4.1.1) são de três tipos: definidos, quando possuem referência demonstrativa (um exemplo desse tipo de referência seria o pronome 'este'), médios ou assertóricos, quando não possuem referência demonstrativa ou pronome indefinido (um exemplo do tipo referência que compõe esses asseríveis seria um nome próprio, 'Sócrates'), e indefinidos, quando são compostos por partículas indefinidas (um exemplo do tipo de referência que compõe esse tipo de asserível seria o pronome indefinido 'alguém'). Já os negativos (a.4.1.2), subdividem-se em: asserível de negação, quando negamos um asserível por completo (e.g., Não é o caso que seja dia), asserível negativo de sujeito, quando negamos o sujeito (e.g., Ninguém caminha), e asserível negativo de predicado, quando utilizamos uma partícula de privação no predicado de um asserível completo (e.g., Este homem é desumano).

Finalmente, os asseríveis completos não-simples (a.4.2) são aqueles formados através de asseríveis simples unidos por conjunções. Eles subdividem-se em asserível condicional (a.4.2.1), asserível disjuntivo exclusivo (a.4.2.2), asserível conjuntivo (a.4.2.3), asserível semi-condicional (a.4.2.4), asserível causal (a.4.2.5), asserível disjuntivo inclusivo (a.4.2.6). Cada um desses asseríveis tem critérios diferentes para avaliar seu valor-verdade. Outrossim, como notaram Kneale e Kneale, os estoicos pareciam não "estar cientes da diferença que há entre proposições verofuncionais e nãoverofuncionais." " Entretanto, como assinala Dinucci (p.56-57), os estoicos tinham à sua disposição critérios vero-funcionais para condicionais (como os dos megáricos Philo e Diodoro) e, ainda assim, optaram por asseríveis que tem seus critérios de verdade para além da verofuncionalidade. Nas palavras do autor, "essa rejeição busca ou evitar o que

\footnotetext{
${ }^{6}$ Cf. Dinucci e Duarte, 2016, p. 20. Trata-se do tópico dos significados que se subdivide em representações e dizíveis, não do tópico das vozes, como uma leitura desatenta poderia indicar.

${ }^{7}$ Ibid., p.27.

${ }^{8}$ Ibid., p.29.

${ }^{9}$ Kneale e Kneale apud Dinucci, 2016, p.59.
} 
alguns chamam hoje de paradoxos da implicação ou valorizar uma noção de implicação que exija uma conexão entre consequente e antecedente." 10

Em Teoria Estoica dos Argumentos, temos a análise e reconstrução da classificação estoica dos argumentos dentro do seu sistema de asseríveis. Segundo Dinucci, “argumentos são entidades incorpóreas e não expressões linguísticas, processos de pensamento ou crenças. Não são asseríveis, mas são compostos por asseríveis." ${ }^{11}$ Eles são compostos por premissas e conclusão - sendo essas, asseríveis completos. Eles são de dois tipos: conclusivo, ou válido, se a partir da condicional "formada pela conjunção das premissas como antecedente e a conclusão como consequente," 12 a consequente se seguir da antecedente; um outro critério ainda seria "um argumento é conclusivo se a contraditória da conclusão é incompatível com a conjunção das premissas"13; se não obedecer a esses critérios, o argumento será do inconclusivo, ou inválido. Ademais, os argumentos são verdadeiros, se além de válidos possuírem premissas verdadeiras, ou falsos, se sequer forem válidos ou se, apesar de válidos, possuírem premissas falsas.

Por seu turno, os argumentos conclusivos se dividem em silogísticos e conclusivos em sentido específico. Os primeiros são ou demonstráveis ou indemonstrados, enquanto os do segundo tipo são ou subsilogísticos ou concludentes de modo não-metódico. No que concerne aos demonstráveis, eles precisam ser reduzidos a um ou mais indemonstrados para que sua validade seja provada. Já os indemonstrados não precisam de demonstração, pois sua validade é óbvia - todavia, podem ser provados. Eles são cinco:

(A1) Se o primeiro, então o segundo; o primeiro; logo, o segundo;

(A2) Se o primeiro, então o segundo; não o segundo; logo, não o primeiro;

(A3) Não é o caso que tanto o primeiro quanto o segundo; o primeiro; logo, não o segundo;

(A4) Ou o primeiro ou o segundo; o primeiro; logo, não o segundo;

(A5) Ou o primeiro ou o segundo; não o primeiro; logo, o segundo. ${ }^{14}$

Para reduzir demonstráveis aos indemonstrados, precisamos dos themata, que são ou regras de corte - como T2, T3 eT4 - ou regra de contraposição- como T1:

\footnotetext{
${ }^{10}$ Ibid., p.57.

${ }^{11}$ Ibid., p.60.

${ }^{12}$ Ibid., p.62.

${ }^{13}$ Ibid., p.63.

${ }^{14}$ Ibid., p.111.
} 
(T1) Se 1, 2 |- C, então 1 (ou 2), CONT181 C |- CONT 2 (ou 1)

(T2) Se 1, 2 |- 3 e 1 (ou 2), 3 |- C, então 1, 2 |- C

(T3) Se 1, 2 |- 3 e 3, E |- C, então 1, 2, E |- C

(T4) Se $1,2 \mid-3$ e 3, 1 (ou 2), E1 ... En $\mid-C$, então 1, 2, E1 ... En $\mid-C^{15}$

Com exceção de T1 e T3, não temos citação textual dos themata, entretanto é possível reconstruir T2 e T4 utilizando o Teorema Dialético e Sintético ${ }^{16}$.

Em seguida, em Solução de Silogismos Estoicos, Duarte e Dinucci reduzem quatorze silogismos (demonstráveis), propostos por Hitchcock, aos indemonstrados, utilizando os themata. É digno de nota que esse trabalho "se trata de uma reconstrução, visto que nenhuma redução nos chegou intacta." 17

A Introdução à lógica proposicional estoica trata-se de uma importante obra de referência para aqueles que desejam se aprofundar nos estudos de lógica estoica, acrescentando conhecimento aos estudos já existentes realizados por Benson Mates, Suzanne Bobzien, Kneale e Kneale et al. Por seu cuidado com o levantamento de fontes e dados históricos, bem como o profundo conhecimento da filosofia estoica, Duarte e Dinucci puderam nos oferecer uma fonte fidedigna para o estudo da lógica estoica, reconstruindo-a e refutando algumas das críticas mais recorrentes a mesma.

O texto pode ser baixado em pdf pelo seguinte link:

\section{https://seer.ufs.br/index.php/prometeus/article/download/5371/4408}

\section{REFERÊNCIAS BIBLIOGRÁFICAS:}

DIÓGENES LAÉRCIO. Lives of Eminent Philosophers. Trad. R. D. Hicks. Harvard: Loeb, 1925.

KNEALE, W.; KNEALE, M. The development of logic. Oxford: Clarendon Press, 1962.

\footnotetext{
${ }^{15}$ Ibid., p.112.

${ }^{16}$ Ibid., cf. p.74.

${ }^{17}$ Ibid., p.78.
} 